\title{
Glacial Expansion during the Early Stade of the Last Glacial Period on Mt. Tateyama, Central Japan
}

\author{
KAWASUMI Takaaki \\ Graduate Student, Department of Geography, Tokyo Metropolitan University, \\ Hachioji, Tokyo 192-0397, Japan
}

\begin{abstract}
This paper reconstructs the flow directions and extent of glaciers on the western slopes of Mt. Tateyama (3,015 m asl) in central Japan from distribution, materials, and facies of two glacial sediments and related deposits. The timing of the larger glacial expansion during the Last Glacial period is then discussed on the basis of their stratigraphic relationships with dated tephras such as K-Tz (95 to $90 \mathrm{ka}$ ), Tt-E (ca. $70 \mathrm{ka}$ ), and DKP (52 to $50 \mathrm{ka}$ ). The wider glacial extension occurred and deposited the Jodosawa Gravel during Murodo Stade I (95 to 70 $\mathrm{ka}$ ) in MIS $5 \mathrm{~b}$ to 4 (marine oxygen isotope stage $5 \mathrm{~b}$ to 4 ). In this substade, the glaciers extended from the non-volcanic Tateyama Main Ridge onto the flat surface of the pyroclastic flow deposits erupted from the Tateyama Volcano, and overflowed to the north from the basin. The glaciers eroded the pyroclastic flow deposits during Murodo Stade I, and extended to at least 2,300 m asl. Between Murodo Stades I and II, the glaciers were forcefully melted by the pumice fall erupted from the Tateyama Volcano, and temporarily retreated upstream. During Murodo Stade II (70 to $50 \mathrm{ka}$ ) in MIS 4 to early MIS 3, the snout of glaciers readvanced to about 2,350 $\mathrm{m}$ asl, and deposited the Murodo Gravel. The glacial readvance was restored in size soon after the pumice fall had finished.
\end{abstract}

Key words: Japanese Alps, glacial sediments, tephrochronology, MIS 5b to 3, glacial fluctuation

\section{Introduction}

Alpine glaciers react to global climate changes so sensitively that reconstructions of their fluctuations in size have been used for understanding the past climate change (Giraudi and Frezzotti 1997). Recent studies in the Himalayas, Andes Mountains and in northern Japan argue that the glacial expansion during MIS 3 (marine oxygen isotope stage 3, Martinson et al. 1987) was larger than those during MIS 2 (Helmens et al. 1997; Thouret et al. 1997; Owen et al. 1997; Richards et al. 2000; Iwasaki et al. 2000a). The glacial fluctuations during MIS 4 and 5, however, have not been reconstructed in detail yet. This is due to a lack of glacial landforms and sediments as a result of erosion, and because their ages are beyond the reach of radiocarbon dating. Thus, the timing of the most extensive glacial advance of the Last Glacial period is still uncertain (Gillespie and Molnar 1995). In the western Himalayas, though some glaciers expanded before the glacial advances of MIS 3, their ages have not been clarified and have been tentatively correlated with MIS 4 or 5 (Owen et al. 1997). In the Hidaka Range of northern Japan, because the glacial expansion of MIS 5 was less extensive than that of MIS 3, the largest glacial advance was tentatively assigned to MIS 6 (Iwasaki et al. 2000b). Therefore, more detailed studies on the extent and timing of glacial expansion during the early stade of the Last Glacial period are still needed to understand the climate changes during the Last Glacial period.

Two glacial sediments associated with the early stade of the Last Glacial period have been found on the west side of Mt. Tateyama (3,015 $\mathrm{m}$ asl) in central Japan, and their ages have been specified in detail (Fukai 1975; Kawasumi 2000). The further study of these glacial sediments is expected to provide important information on glacial extent during the early stade of the Last Glacial period in the Japanese Alps. This paper describes the distribution and facies 
of these glacial sediments and related deposits, examines the flow directions and extent of glaciers, and defines the timing of the larger glacial expansion during the Last Glacial period on the basis of their stratigraphic relationships with dated volcanic ejecta.

\section{Study Area and Previous Studies}

No glaciers exist today in Japan, but glacial landforms and sediments of the Last Glacial period are preserved on several mountain ranges in northern and central Japan. Most of these glacial landforms suggest that only cirque and short valley glaciers occurred in Japan during the Last Glacial period. Relatively large glaciers, however, were formed on the Hida Range of central Japan near Japan Sea, which is the main source of moisture for the winter snow (Iozawa 1979).

Mt. Tateyama $(3,015 \mathrm{~m}$ asl $)$ is located in the northwestern part of the Hida Range (Figure 1). It consists of the non-volcanic Tateyama Main Ridge with some peaks such as Bessan $(2,880 \mathrm{~m}$ asl) and Jodosan $(2,831 \mathrm{~m}$ asl), and of the Tateyama Volcano (over 2,600 $\mathrm{m}$ asl), which is situated on the west side of the main ridge (Figure 2). One of the main divides, Dainichi Ridge, extends westward from Bessan Peak, and the Murodo-nokkoshi Saddle (about 2,360 $\mathrm{m}$ asl) is on this ridge between Bessan Peak and Mt. Okudainichidake $(2,606 \mathrm{~m}$ asl). The Tateyama Main Ridge and Dainichi Ridge are composed mainly of diorite and granite (Harayama et al. 2000: 38-51).

The Tateyama Volcano repeatedly erupted throughout the late Pleistocene, producing pyroclastic materials and lava flows (Yamasaki et al. 1966). The history of this volcano can be divided into four stages as follows: 1) the stratovolcano was made up of several lava flows, for example, the Zaimokuiwa; 2) the volcanic pla-

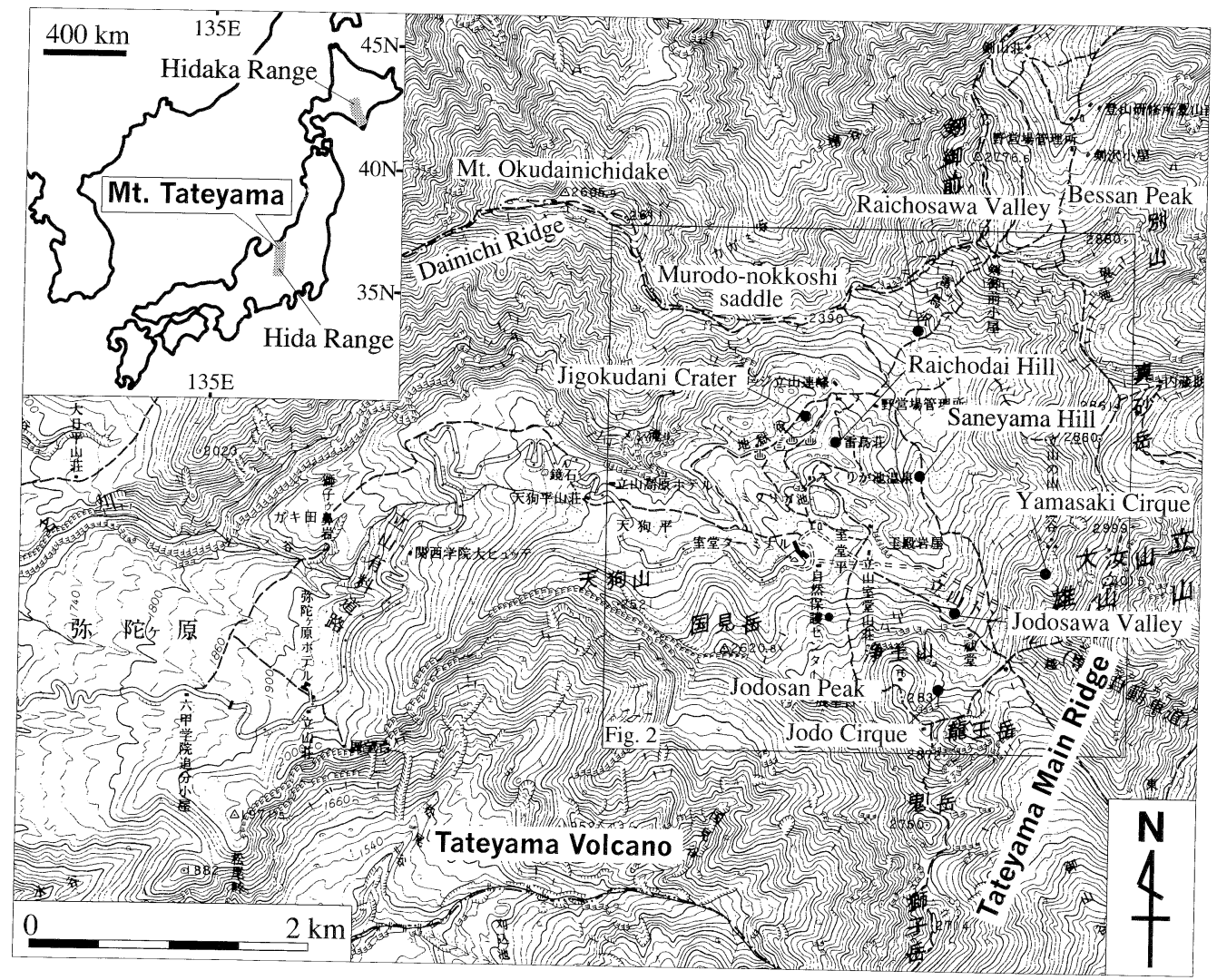

Figure 1. Topography of the study area, Mt. Tateyama, Hida Range, central Japan.

Base map is 1/50,000 topographical map "Tateyama" published by the Geographical Survey Institute of Japan. Contour interval is $20 \mathrm{~m}$. 


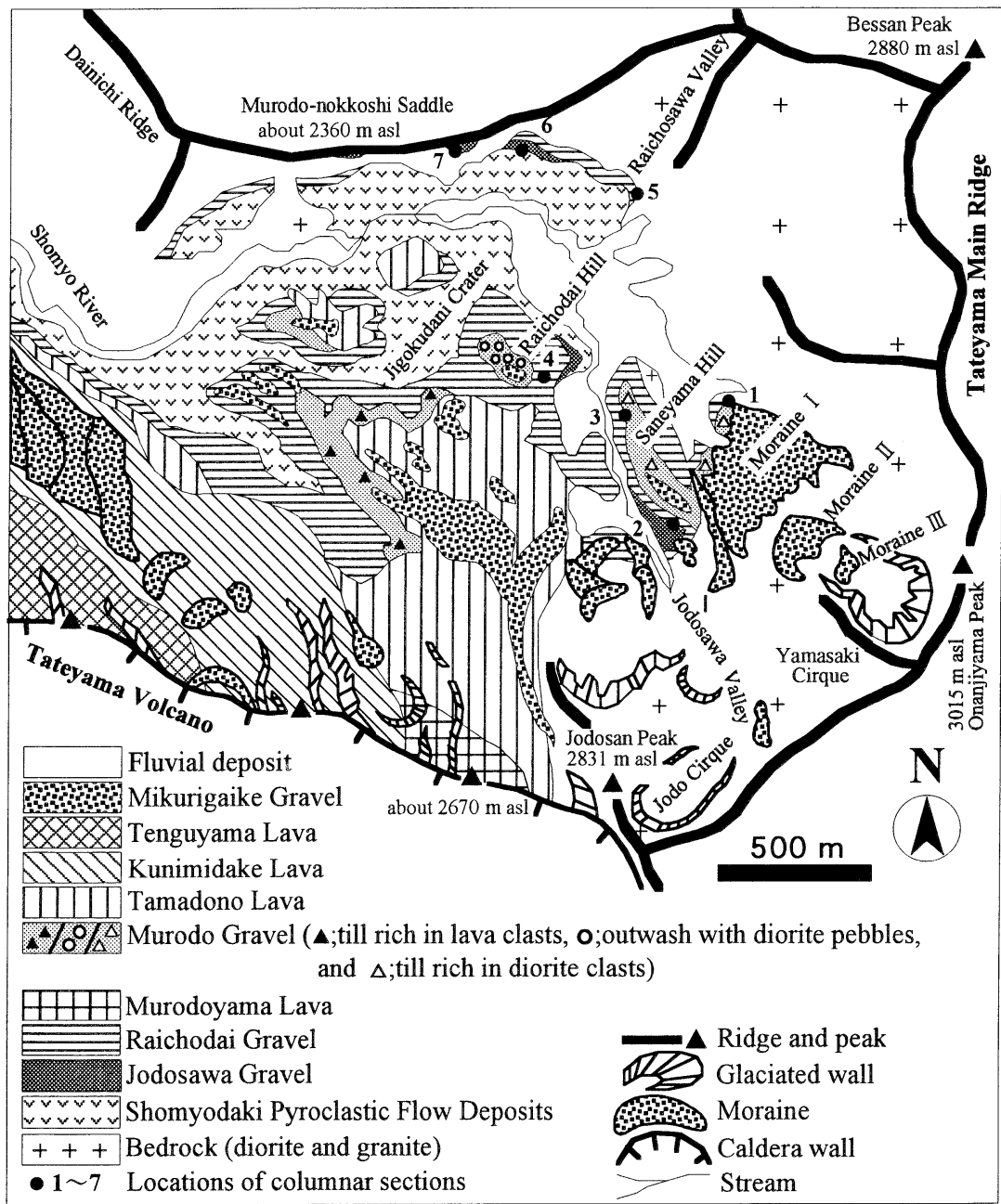

Figure 2. Map showing the distribution of volcanic ejecta and glacial sediments on the west side of Mt. Tateyama (from Kawasumi 2000).

The area included is shown in Figure 1.

teaus were constructed from pyroclastic materials, named the Shomyodaki Pyroclastic Flows deposits; 3) the pumices correlated with the Tateyama E tephra (Tt-E) were produced; and 4) accessory tephras were discharged by phreatomagmatic explosions and the explosive crater called the Jigokudani Crater was formed in the northeastern most part of the volcanic plateaus (Table 1). The northern slopes of the Tateyama Volcano are dissected by shallow glacial valleys, which extend in the northern volcanic plateaus region (Kobayashi 1990). Moraines are preserved on the plateaus, but the phreatomagmatic explosions have deformed their shapes around the Jigokudani Crater (Kobayashi
1990). These moraines are composed of Mikurigaike Gravel, which has been thought to accumulate during the late stade of the Last Glacial period (Kobayashi 1990).

Two glacial cirques, called the Yamasaki Cirque and the Jodo Cirque, hang on the western flank of the Tateyama Main Ridge (Figure 2). Three distinct terminal moraines (I, II, and III, in ascending order) lie just below and within the Yamasaki Cirque at 2,350 to 2,705 $\mathrm{m}$ asl (Figure $3)$. These moraines are thought to be formed during the late stade of the Last Glacial period, named the Tateyama Stade (Fukai 1975). The narrow NS-trending Saneyama Hill, about 400 $\mathrm{m}$ long, 50 to $60 \mathrm{~m}$ high, is located below the 
Table 1. Stratigraphy and glacial sequence on the west side of Mt. Tateyama

\begin{tabular}{lc}
\hline \multicolumn{1}{c}{ Stratigraphy } & Glacial stade \\
\hline $\begin{array}{l}\text { Peat layers with accessory tephras and wood chips (8.8 ka) } \\
\text { Mikurigaike Gravel }\end{array}$ & Tateyama Stade (52-8.8 ka) \\
DKP (52-50 ka) & \\
\hline Murodo Gravel & Murodo Stade II (70-50 ka) \\
Raichodai Gravel (Tt-E, ca. 70 ka) & Murodo Stade I (95-70 ka) \\
Jodosawa Gravel/Tateyama Gravel (Kawasumi 2000) & \\
\hline K-Tz (95-90 ka) & \\
Shomyodaki Pyroclastic Flow Deposits (130-95 ka) &
\end{tabular}

Stratigraphy is from Yamasaki et al. (1966), Fukai (1975), Machida and Arai (1979), Kobayashi (1990), and Kawasumi (2000). Ages of tephras and wood chips are from Yoshii and Oritani (1987), Nakamura et al. (1992), Machida and Arai (1992), Kimura (1996), and Machida (1999).

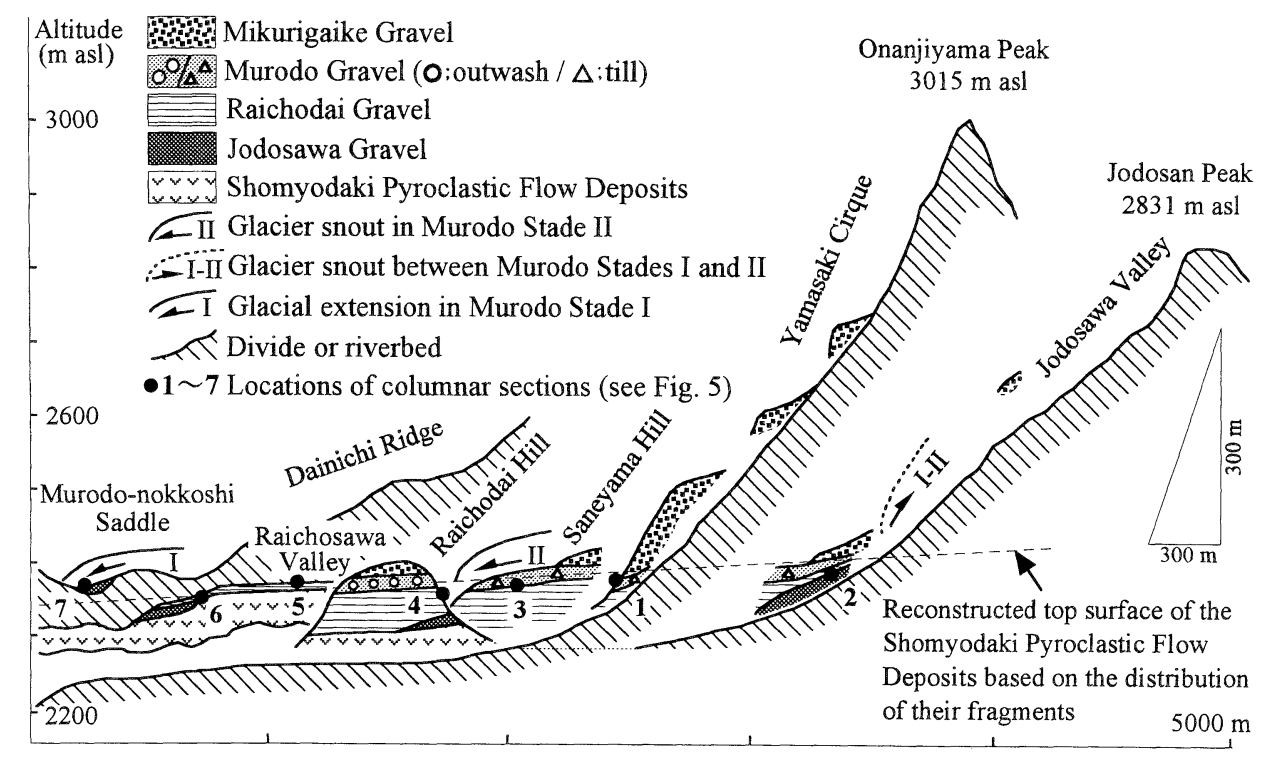

Figure 3. Longitudinal profiles of landforms and sediments along the present riverbed in the Jodosawa Valley and in the Yamasaki Cirque.

moraines of the Yamasaki Cirque. The southern extension of Saneyama Hill reaches the moraines of the Jodosawa Valley at around 2,400 $\mathrm{m}$ asl.

Glacial sequence of the west side of Mt. Tateyama is shown in Table 1 . The early stade of the Last Glacial period (Murodo Stade) have been argued on the basis of two glacial sediments: the Jodosawa Gravel and the Murodo Gravel (Fukai 1975; Machida and Ito 1996; Kawasumi 2000). The glacial sediments of the earlier substade were previously identified by
Kawasumi (2000) and were named the Tateyama Gravel. Here, I change the name of Tateyama Gravel to Jodosawa Gravel in order to avoid confusion between the Tateyama Gravel and the Tateyama Stade.

The Raichodai Gravel is the key bed that separates the Jodosawa Gravel from the Murodo Gravel in a stratigraphic section (Kawasumi 2000). The Raichodai Gravel is the deposit of debris flow, which occurred when the glaciers on the western slopes of the Tateyama Main Ridge were forcefully melted by the fall of 
pumices (Kawasumi 2000). Thus, the Raichodai Gravel could be identified by the pumices, which were correlated with Tt-E on the basis of refractive indices ( $\gamma=1.715$ to 1.722 ) of orthopyroxenes (Machida and Arai 1979, 1992). The age of Tt-E was estimated to be about $70 \mathrm{ka}$ in the early to middle MIS 4 on the basis of its stratigraphic relationships with other dated tephras and pollen analysis (Kimura 1996).

The Jodosawa Gravel was found only on the southern side of Saneyama Hill and on Raichodai Hill (Machida and Ito 1996; Kawasumi 2000), and its distribution has not yet been traced in detail. Some glacial sediments were observed in the vicinity of the Murodonokkoshi Saddle (Harayama et al. 2000: 152164), though their distribution and stratigraphic horizon have not yet been identified.

The Murodo Gravel rich in lava clasts lies southwest to west of the Jigokudani Crater, and appears to have been deposited by the glaciers from the Tateyama Volcano (Fukai 1975; Kawasumi 2000). The southeastern margin of the Jigokudani Crater is called Raichodai Hill, where the Murodo Gravel includes a large quantity of diorite pebbles and shows fluvial sedimentary structures (Fukai 1975; Harayama et al. 2000: 152-164). These previous studies did not recognize the Murodo Gravel deposited by the glaciers from the Tateyama Main Ridge.

\section{The Shomyodaki Pyroclastic Flow Deposits}

The Shomyodaki Pyroclastic Flow Deposits are continuously distributed in Raichosawa Valley and below the Murodo-nokkoshi Saddle along Dainichi Ridge (Locs. 5 and 6 in Figure 2). These deposits comprise andesitic clasts (5 to $60 \mathrm{~cm}$ in diameter), scoria (10 to $30 \mathrm{~cm}$ in diameter), pumices (5 to $30 \mathrm{~cm}$ in diameter), and fine materials. Distinctive subhorizontal bands (1 to $8 \mathrm{~m}$ thick) are observed throughout the deposits (Figure 4). Each band comprises a cluster of andesitic clasts. At Raichosawa Valley, the top surface of the Shomyodaki Pyroclastic Flow Deposits is a subhorizontal plane at 2,340 to $2,350 \mathrm{~m}$ asl and is covered with the Raichodai Gravel (Loc. 5 in Figure 3). On the other hand, below the Murodo-nokkoshi Saddle, the top sur-

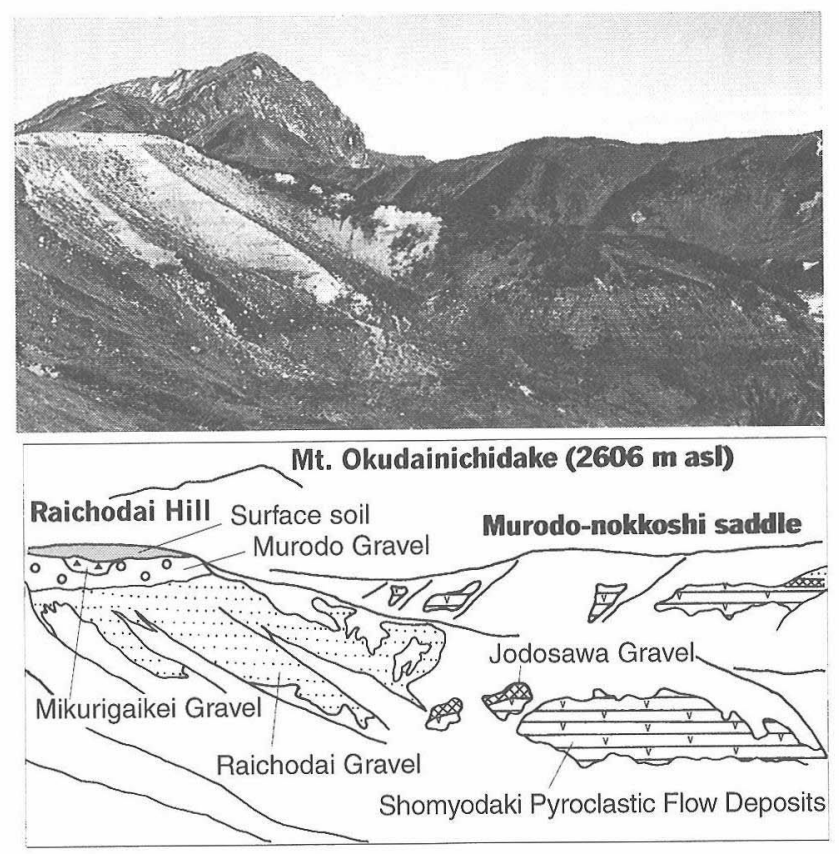

Figure 4. Raichodai Hill and Murodo-nokkoshi Saddle viewed from the southeast. The Shomyodaki Pyroclastic Flow Deposits exhibit distinctive subhorizontal banding. The Raichodai Gravel exposed on Raichodai Hill is more than $50 \mathrm{~m}$ thick and consists of debris flow deposits showing a rhythmic alternation of gravel beds and fine-material beds. 
face of the Shomyodaki Pyroclastic Flow Deposits descends at $2,335 \mathrm{~m}$ asl and is covered with the Jodosawa Gravel (Loc. 6 in Figure 3).

The Shomyodaki Pyroclastic Flow Deposits are also exposed at the base of Raichodai Hill (Figure 4). The deposits here also consist of andesitic clasts, scoria, pumices, and fine materials and exhibit subhorizontal banding. The top surface of the deposits is at 2,312 to $2,325 \mathrm{~m}$ asl on the southeastern side of the hill and at $2,300 \mathrm{~m}$ asl on the northwestern side of the hill, where this surface gently dips toward the northwest. This top surface cuts the subhorizontal bands at a low angle and is covered with the Jodosawa Gravel.

\section{The Jodosawa Gravel}

The Jodosawa Gravel, which is the lower till of the Murodo Stade, is exposed on the southern side of Saneyama Hill and at Raichodai Hill. Glacial sediments in the vicinity of the Murodonokkoshi Saddle were identified as Jodosawa Gravel, as mentioned below.

On the southern side of Saneyama Hill, the Jodosawa Gravel, more than $10 \mathrm{~m}$ thick, is exposed between 2,380 and 2,390 m asl just below the Raichodai Gravel (Loc. 2 in Figure 5). It consists of overconsolidated sediments, comprising angular clasts ( 1 to $30 \mathrm{~cm}$ in diameter) of the Shomyodaki Pyroclastic Flow Deposits, diorite clasts ( 3 to $80 \mathrm{~cm}$ in diameter), and yellowish gray clay. The uppermost part (about 1 $m$ thick) of the Jodosawa Gravel includes a few pumices ( 1 to $2 \mathrm{~cm}$ in diameter). The refractive indices $(\gamma)$ of orthopyroxenes in these pumices range from 1.714 to 1.720 (Table 2). Since the indices nearly coincide with those of Tt-E, the pumices may be correlated with Tt-E. Numerous shear planes and low-angle joints traverse

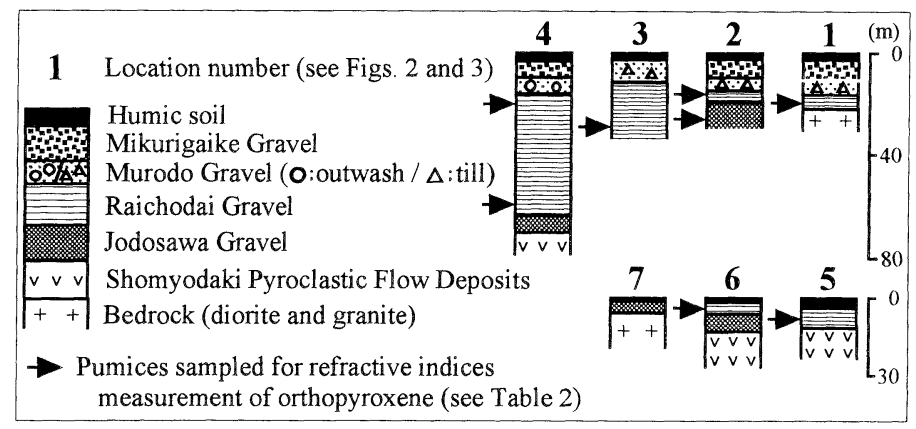

Figure 5. Columnar sections of exposures at the locations shown in Figures 2 and 3.

Table 2. Refractive indices of volcanic ejecta

\begin{tabular}{ccc}
\hline Location & Horizon & $\begin{array}{c}\text { Refractive indices } \\
\text { of orthopyroxene }\end{array}$ \\
\hline Loc. 1 & Raichodai Gravel & $1.716-1.722$ \\
Loc. 2 & Raichodai Gravel & $1.716-1.722$ \\
Loc. 3 & Uppermost Jodosawa Gravel & $1.714-1.720$ \\
Loc. 4 & Raichodai Gravel & $1.713-1.722$ \\
Loc. 5 & Upper Raichodai Gravel & $1.715-1.722$ \\
Loc. 6 & Lower Raichodai Gravel & $1.713-1.718$ \\
\hline & Raichodai Gravel & $1.715-1.721$ \\
\hline
\end{tabular}

Locations and horizons are shown in Figures 2 and 5, respectively. The indices of Tt-E are from Machida and Arai (1992). 

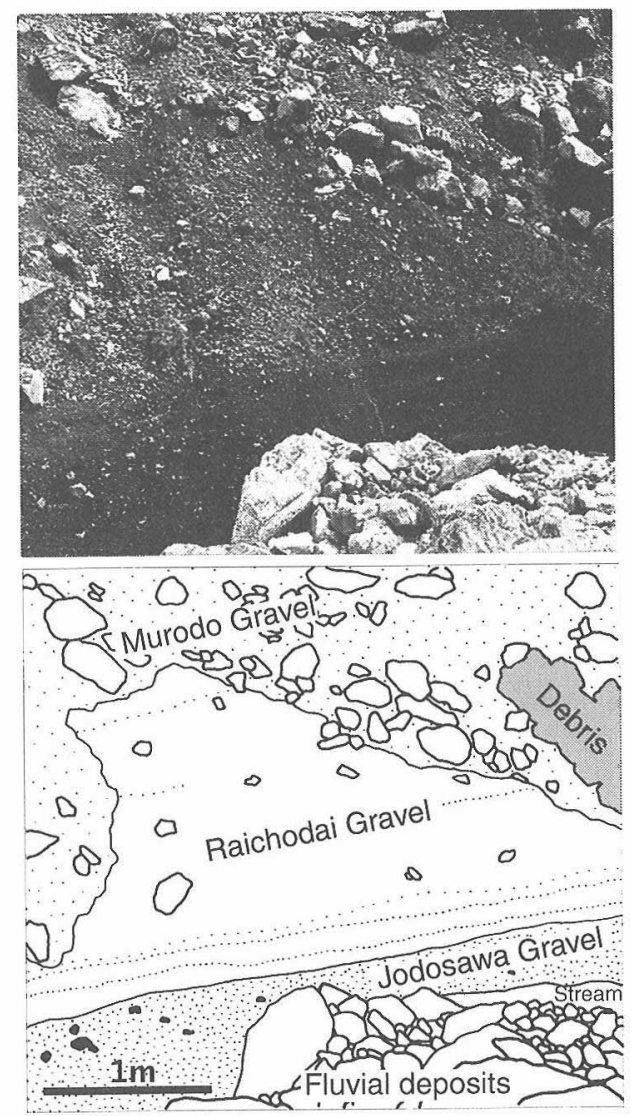

Figure 6. Outcrop on the southern side of Saneyama Hill (Loc. 2).

The Jodosawa Gravel shows numerous shear planes, low-angle joints and a subhorizontal fissile structure. The Raichodai Gravel exhibits parallel laminae dipping gently toward the north in the lowermost part. The compact Murodo Gravel unconformably overlies the Raichodai Gravel.

the Jodosawa Gravel, which shows a subhorizontal fissile structure (Figure 6). Because these structures suggest subglacial overburden pressure and shearing (Flint 1971: 148-155; Sugden and John 1976: 214-234; Benn and Evans 1998: 386-404), the Jodosawa Gravel may be regarded as subglacial till.

At the Raichodai Hill, the Jodosawa Gravel lies, more than $3 \mathrm{~m}$ thick, fragmentarily on the surface of the Shomyodaki Pyroclastic Flow Deposits, and underlies the Raichodai Gravel (Loc. 4 in Figure 5). It is compact sediment composed of angular clasts (5 to $40 \mathrm{~cm}$ in diameter) of the Shomyodaki Pyroclastic Flow Deposits, diorite clasts (around $10 \mathrm{~cm}$ in diame-

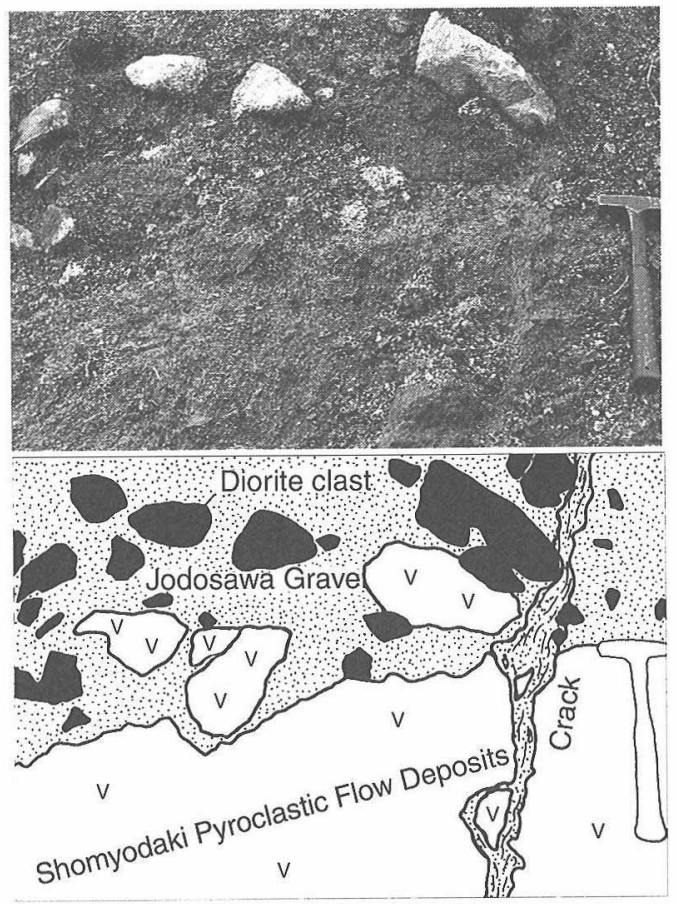

Figure 7. A high-angle crack traced downward from the lower part of the Jodosawa Gravel to the underlying Shomyodaki Pyroclastic Flow Deposits on the south side of the Murodo-nokkoshi Saddle.

Overconsolidated fine materials in the crack show laminae parallel to the crack walls.

ter), and yellowish gray clay matrix. This sediment shows brittle fracture features in the form of numerous low-angle shear planes and irregular joints.

Glacial sediment below the Murodo-nokkoshi Saddle overlies the Shomyodaki Pyroclastic Flow Deposits and underlies the Raichodai Gravel (Loc. 6 in Figure 5). On the basis of these stratigraphic relationships, this glacial sediment is identified as Jodosawa Gravel. Here, the Jodosawa Gravel, $7 \mathrm{~m}$ thick, consists of compact yellowish gray clay, angular clasts (1 to $30 \mathrm{~cm}$ in diameter) of diorite and granite, and clasts ( 5 to $40 \mathrm{~cm}$ in diameter) of the Shomyodaki Pyroclastic Flow Deposits. High-angle cracks, 2 to $10 \mathrm{~cm}$ wide, 1 to $3 \mathrm{~m}$ long, reach downward from the lower part of the Jodosawa Gravel to the uppermost part of the Shomyodaki Pyroclastic Flow Deposits (Figure 7). These cracks 


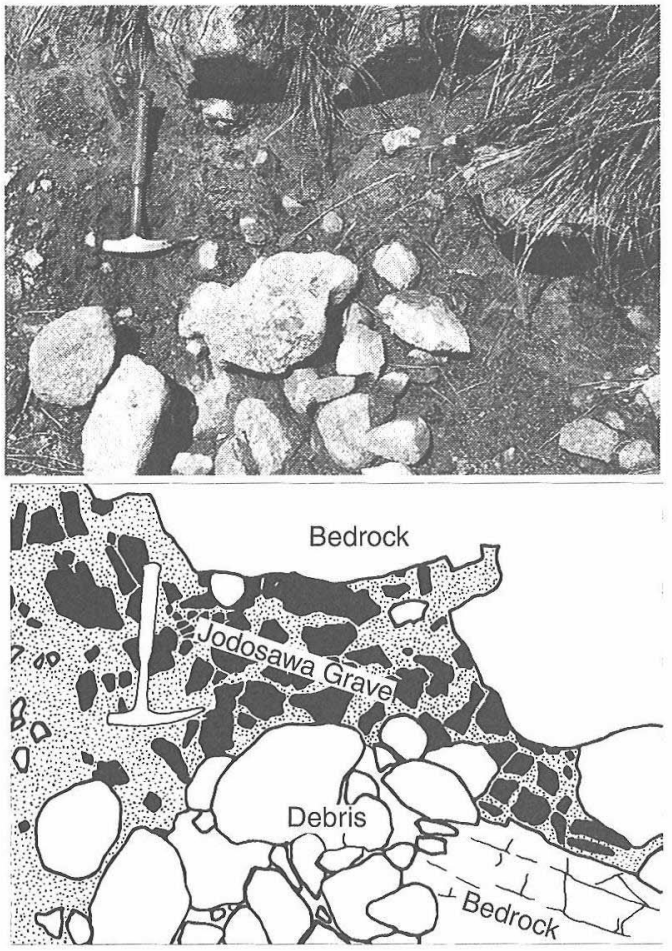

Figure 8. The Jodosawa Gravel is crammed into the cavity of diorite bedrock at 2,385 $\mathrm{m}$ asl on the Murodo-nokkoshi Saddle.

This sediment includes fine clasts of the Shomyodaki Pyroclastic Flow Deposits, which lie below $2,335 \mathrm{~m}$ asl on the southern side of the saddle.

are filled with fine clasts and compact clay, which show laminae roughly parallel to the crack walls. Because these overconsolidation and deformation suggest excessive overburden pressure and shearing, the Jodosawa Gravel is considered as a subglacial till.

On the Murodo-nokkoshi Saddle at 2,365 to 2,385 $\mathrm{m}$ asl, a glacial sediment is distributed fragmentarily. This sediment is composed of yellowish gray clay, diorite clasts (10 to $20 \mathrm{~cm}$ in diameter), and fine clasts of the Shomyodaki Pyroclastic Flow Deposits. Because the sediment contains clasts of the Shomyodaki Pyroclastic Flow Deposits and lacks pumices of Tt-E, it is stratigraphically above the Shomyodaki Pyroclastic Flow Deposits and below the Raichodai Gravel (Loc. 7 in Figure 5). Therefore, the sediment is identified as Jodosawa Gravel. At $2,385 \mathrm{~m}$ asl on the saddle, the overconsoli- dated Jodosawa Gravel is stuffed into cavities of diorite bedrock (Figure 8), and includes fine clasts of the Shomyodaki Pyroclastic Flow Deposits. Since the Shomyodaki Pyroclastic Flow Deposits are distributed on the south side of the saddle below $2,335 \mathrm{~m}$ asl, it appears that the fine clasts were transported upslope from the south side of the saddle. Only glacial agency can account for upslope transportation and consolidation of materials. Therefore, the Jodosawa Gravel on the saddle is interpreted as a glacial till.

\section{The Raichodai Gravel}

The Raichodai Gravel, widely distributed, includes large clasts of diorite just below the Tateyama Main Ridge (Locs. 1 to 4), but comprises only fine materials along the Dainichi Ridge (Locs. 5 and 6).

At Raichodai Hill the Raichodai Gravel, more than $50 \mathrm{~m}$ thick, overlies the Jodosawa Gravel and conformably underlies the Murodo Gravel (Loc. 4 in Figure 5). No buried soil or weathered layers lie between the Jodosawa Gravel and the Raichodai Gravel, and between the Raichodai Gravel and the Murodo Gravel. Here, the Raichodai Gravel consists of a rhythmic alternation of matrix-supported gravel beds and finematerial beds. The matrix-supported gravel beds largely comprise angular and rounded pumices ( 1 to $60 \mathrm{~cm}$ in diameter), sand, angular clasts (10 to $160 \mathrm{~cm}$ in diameter) of diorite, and scoria (5 to $30 \mathrm{~cm}$ in diameter). The finematerial beds consist mainly of angular and rounded pumices (1 to $20 \mathrm{~cm}$ in diameter), sand, silt, and fine diorite clasts. No buried soil or weathered layers exist between these alternating beds.

At the base of Moraine I below the Yamasaki Cirque, the Raichodai Gravel, $5 \mathrm{~m}$ thick, is exposed at 2,350 to $2,355 \mathrm{~m}$ asl and is covered with the non-stratified Murodo Gravel (Loc. 1 in Figure 5). The Raichodai Gravel consists of stratified deposits dipping toward the northwest at 17 to 19 degrees, and comprises angular and rounded pumices (2 to $15 \mathrm{~cm}$ in diameter), angular clasts ( 1 to $20 \mathrm{~cm}$ in diameter) of the Shomyodaki Pyroclastic Flow Deposits, diorite clasts (3 to $10 \mathrm{~cm}$ in diameter), and sand. 
On the southern side of Saneyama Hill, the Raichodai Gravel, 3 to $6 \mathrm{~m}$ thick, lies on the Jodosawa Gravel and unconformably underlies the Murodo Gravel (Loc. 2 in Figure 5). The Raichodai Gravel here has a similar lithology to Loc. 1 but with different sized particles: angular and rounded pumices ( 1 to $20 \mathrm{~cm}$ in diameter), angular clasts (1 to $5 \mathrm{~cm}$ in diameter) of the Shomyodaki Pyroclastic Flow Deposits, and diorite clasts (20 to $60 \mathrm{~cm}$ in diameter).

On the northern side of Saneyama Hill, the Raichodai Gravel, more than $20 \mathrm{~m}$ thick, underlies the Murodo Gravel (Loc. 3 in Figure 5). This Raichodai Gravel consists of crudely stratified sediments, comprising angular and rounded pumices ( 1 to $30 \mathrm{~cm}$ in diameter), angular clasts (1 to $40 \mathrm{~cm}$ in diameter) of the Shomyodaki Pyroclastic Flow Deposits, and diorite clasts (10 to $60 \mathrm{~cm}$ in diameter).

At Raichosawa Valley the Raichodai Gravel, 2 to $3 \mathrm{~m}$ thick, lies on the flat surface of the Shomyodaki Pyroclastic Flow Deposits (Loc. 5 in Figure 5). This Raichodai Gravel consists of sand, angular and rounded pumices $(1$ to $5 \mathrm{~cm}$ in diameter), and fine clasts of diorite and granite. The sand exhibits horizontal lamination throughout the deposit.

Below the Murodo-nokkoshi Saddle, the Raichodai Gravel, 1 to $4 \mathrm{~m}$ thick, overlies the Jodosawa Gravel, and underlies the humus soil (Loc. 6 in Figure 5). This sediment mainly comprises sand, angular and rounded pumices ( 1 to $7 \mathrm{~cm}$ in diameter), and fine clasts of diorite and granite. Coarse laminae of sand are found throughout the deposit.

The refractive indices $(\gamma)$ of orthopyroxenes in the pumices at these locations range from 1.713 to 1.722 (Table 2). These values nearly coincide with those of Tt-E, and thus, the pumices may be correlated with Tt-E erupted from the Tateyama Volcano.

The Raichodai Gravel includes a large amount of diorite clasts and becomes thinner from Raichodai Hill toward the northwest. Therefore, the materials of the Raichodai Gravel appear to have been supplied from the western slopes of the Tateyama Main Ridge. The Raichodai Gravel consists of alternations of matrix-supported gravel beds and finematerial beds at Raichodai Hill, but of only fine-material beds on the downstream side of Raichodai Hill. Because these depositional structures represent repetition of mass transport and traction current (Benn and Evans 1998: 406-411), the Raichodai Gravel is considered to be debris flow deposits. Outbreak of a debris flow needs abrupt occurrence of huge surface flow (Suwa 1992). The Raichodai Gravel includes the pumices through the alternations to more than $50 \mathrm{~m}$ thick. This suggests that huge surface flows repeatedly occurred and caused the debris flows during the fall of pumices on the western slopes of the Tateyama Main Ridge. A few pumices of Tt-E are found in the uppermost part of the Jodosawa Gravel on the southern side of Saneyama Hill. Because the superglacial materials are transported to the glacier bed through crevasses and holes (Benn and Evans 1998:216-221), the pumices in the Jodosawa Gravel must have been transported from the glacier surfaces. In brief, the glaciers remained on the western slopes of the Tateyama Main Ridge at the beginning of the pumice fall. Therefore, it appears that the pumice fall melted the glacier ice, producing the debris flows. Thus, the Raichodai Gravel consists of the sediments of debris flows, which occurred when the glaciers on the western slopes of the Tateyama Main Ridge were forcefully melted by the fall of pumices, erupted from the Tateyama Volcano.

\section{The Murodo Gravel}

The unstratified Murodo Gravel, which is the upper till of the Murodo Stade, is distributed at the base of Moraine I below the Yamasaki Cirque and in Saneyama Hill. The crudely stratified Murodo Gravel lies in Raichodai Hill (Figure 2).

At the base of Moraine I below the Yamasaki Cirque, the Murodo Gravel, more than $3 \mathrm{~m}$ thick, is exposed at around 2,355 $\mathrm{m}$ asl between the Raichodai Gravel and the moraine sediments of the Yamasaki Cirque (Figure 9). This Murodo Gravel consists of compact sediments, comprising dark reddish brown clay and silt, angular clasts ( 3 to $80 \mathrm{~cm}$ in diameter) of diorite and granite, and clasts ( 2 to $7 \mathrm{~cm}$ in diameter) of the Shomyodaki Pyroclastic Flow Deposits. 


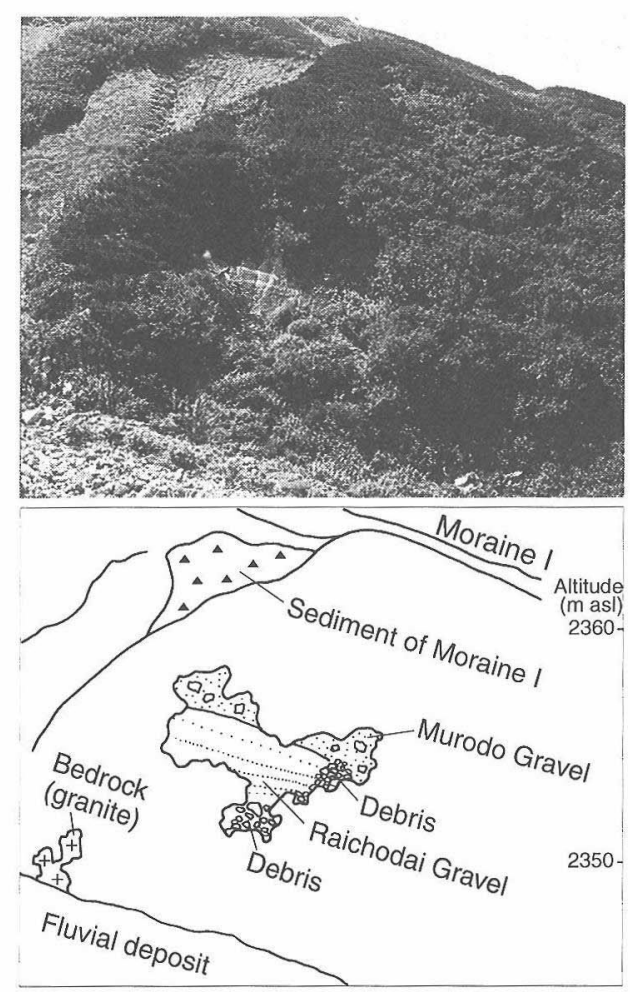

Figure 9. Base of Moraine I below the Yamasaki Cirque (Loc. 1).

The compact Murodo Gravel lies just above the stratified Raichodai Gravel and underlies the loose moraine sediment.

In Saneyama Hill the Murodo Gravel, 7 to 10 $\mathrm{m}$ thick, is exposed at 2,393 to $2,400 \mathrm{~m}$ asl on the southern side of the hill and at 2,340 to $2,350 \mathrm{~m}$ asl on the northern side of the hill, dipping gently toward the north (Figure 3). On the southern side of the hill at around 2,400 m asl, the Murodo Gravel unconformably overlies the Raichodai Gravel and unconformably underlies the moraine sediments of Jodosawa Valley (Loc. 2 in Figure 5). This Murodo Gravel also comprises dark reddish brown clay and silt, angular clasts ( 3 to $90 \mathrm{~cm}$ in diameter) of diorite and granite, and clasts $(2$ to $7 \mathrm{~cm}$ in diameter) of the Shomyodaki Pyroclastic Flow Deposits. On the northern side of the hill (Loc. 3), a clay band rising northward at 15 to 25 degrees divides the Murodo Gravel into upper and lower layers (Figure 10). This band, 10 to $25 \mathrm{~cm}$ thick, consists of yellowish gray clay with fine diorite clasts. Abraded clasts (20 to 60 $\mathrm{cm}$ in diameter) of diorite and granite scatter in

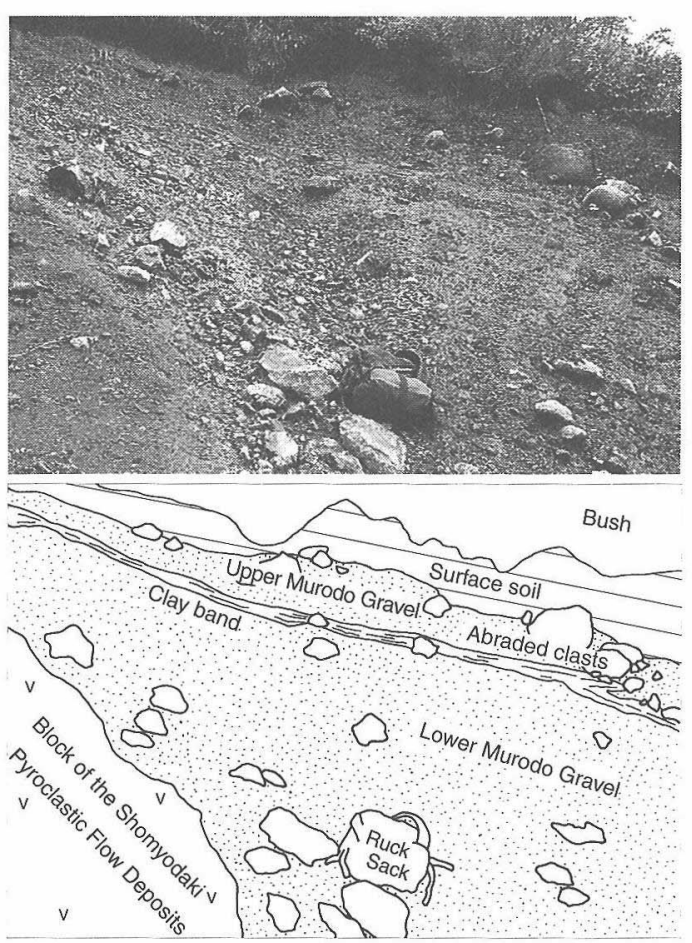

Figure 10. The Murodo Gravel exposed on the northern side of Saneyama Hill (Loc. 3).

A clay band climbs gently upslope at a low angle. Well-abraded clasts are concentrated adjacent to the band.

the upper layer, but few abraded clasts exist in the lower layer. Notably abraded diorite clasts (50 to $60 \mathrm{~cm}$ in diameter) are adjacent to the band. Thus, the clay band can be regarded as a shear zone with intensive modification between the deformed upper layer and the undeformed lower layer, suggesting that the upper layer was dragged and deformed beneath sliding glaciers. Therefore, the Murodo Gravel at the base of Moraine I below the Yamasaki Cirque and at Saneyama Hill is considered to be a subglacial till deposited by the glaciers from the Tateyama Main Ridge.

At Raichodai Hill, the Murodo Gravel conformably lies on the Raichodai Gravel, and unconformably underlies the Mikurigaike Gravel (Figure 4). The Murodo Gravel is exposed at 2,365 to $2,370 \mathrm{~m}$ asl on the southeastern side of the hill, at 2,350 to $2,355 \mathrm{~m}$ asl on the northwestern side of the hill, and dips gently toward the northwest (Figure 3). This Murodo Gravel 


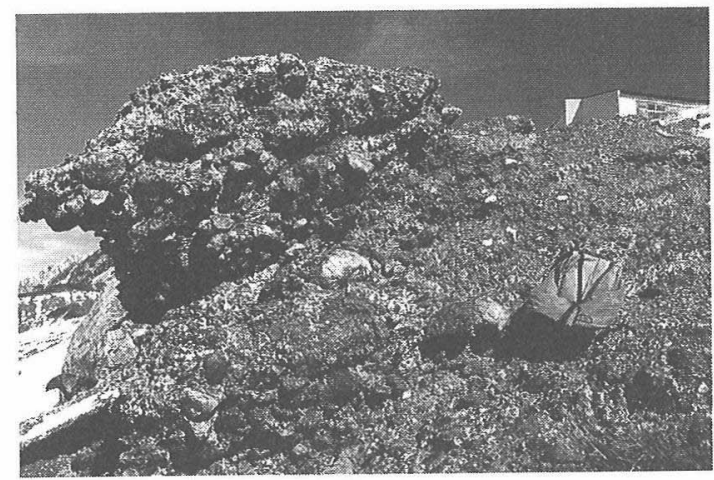

Figure 11. Tor-like block of Murodo Gravel exposed on the northwestern side of Raichodai Hill.

The Murodo Gravel consists of crudely stratified sediment, comprising largely diorite pebbles, silt, and sand.

consists of crudely stratified and clastsupported gravel beds, comprising diorite pebbles ( 2 to $50 \mathrm{~cm}$ in diameter), silt, and sand (Figure 11). The sand particles are well rounded. The matrices of these beds exhibit parallel lamination of silt and sand among the pebbles. The laminae, 1 to $4 \mathrm{~mm}$ thick, are roughly parallel to the bedding plane. These facies indicate that the Murodo Gravel consists of fluvial deposits. Raichodai Hill is located just on the downstream side of Saneyama Hill occupied by the subglacial till of the Murodo Gravel. The Murodo Gravel shows continual distribution from Saneyama Hill to Raichodai Hill in the longitudinal profiles of landforms (Figure 3). Consequently, the Murodo Gravel of Raichodai Hill is considered as proglacial outwash deposit.

\section{Discussion}

\section{The former top surface of the Shomyodaki Pyroclastic Flow Deposits}

The top surface of the Shomyodaki Pyroclastic Flow Deposits lies almost horizontally at Raichosawa Valley (Figure 3). The Shomyodaki Pyroclastic Flow Deposits exhibit subhorizontal lithologic banding at Raichodai Hill, Raichosawa Valley, and below the Murodonokkoshi Saddle. These facts show that the Shomyodaki Pyroclastic Flow Deposits accu- mulated subhorizontally and formed a nearly level surface.

Clasts of the Shomyodaki Pyroclastic Flow Deposits are included in the Raichodai Gravel that is exposed at 2,350 to $2,355 \mathrm{~m}$ asl at the base of Moraine I below the Yamasaki Cirque. Clasts are also included in the Jodosawa Gravel exposed at 2,380 to $2,390 \mathrm{~m}$ asl on the southern side of Saneyama Hill, appearing to have been transported from above. Therefore, the Shomyodaki Pyroclastic Flow Deposits must have been distributed on the western slopes of the Tateyama Main Ridge at altitudes of more than $2,355 \mathrm{~m}$ asl. At Raichosawa Valley, the flat surface of the Shomyodaki Pyroclastic Flow Deposits is at 2,340 to $2,350 \mathrm{~m}$ asl. Thus, the reconstructed former surface of the Shomyodaki Pyroclastic Flow Deposits is a nearly flat plane dipping gently from the Tateyama Main Ridge toward Raichosawa Valley at altitudes of 2,340 to 2,350 $\mathrm{m}$ asl (Figure 3).

\section{Glacial expansion during deposition of the Jo- dosawa Gravel}

Because the Jodosawa Gravel on the southern side of Saneyama Hill and Raichodai Hill, and below the Murodo-nokkoshi Saddle, includes many clasts of diorite that come from the bedrock of the non-volcanic Tateyama Main Ridge, the glaciers are thought to have advanced from the Tateyama Main Ridge near the saddle. On the Murodo-nokkoshi Saddle, the Jodosawa Gravel includes fine clasts of Shomyodaki Pyroclastic Flow Deposits. These fine clasts were transported upslope by the glaciers from the south side of the saddle. The height of the Murodo-nokkoshi Saddle was only 10 to $20 \mathrm{~m}$ above the former flat surface of the Shomyodaki Pyroclastic Flow Deposits. Therefore, it appears that the glaciers extended from the Tateyama Main Ridge onto the flat surface of the Shomyodaki Pyroclastic Flow Deposits, and reached the Murodo-nokkoshi Saddle. A part of the glacier crossed to the north side of the saddle (Figure 3).

At Raichodai Hill, the top surface of the Shomyodaki Pyroclastic Flow Deposits dips toward the northwest and cuts the subhorizontal bands of the deposits, being covered with the Jodosawa Gravel. Therefore, the top surface 
seems to have been eroded by glaciers from the Tateyama Main Ridge. Because this surface can be traced down to 2,300 $\mathrm{m}$ asl on the northwestern side of Raichodai Hill, it is considered that the glaciers eroded the Shomyodaki Pyroclastic Flow Deposits and descended to at least $2,300 \mathrm{~m}$ asl in the vicinity of Raichodai Hill. However, the terminal positions of the glaciers are unclear because explosions have disturbed the landforms and sediments around the Jigokudani Crater.

\section{Glacial retreat during deposition of the Rai- chodai Gravel}

The Raichodai Gravel, more than $50 \mathrm{~m}$ thick, is composed of rhythmic alternating beds of gravel and fine material at Raichodai Hill. Because no buried soils or noticeably weathered layers exist between these alternating beds, the Raichodai Gravel must have accumulated without interruption in a short time. At the southern side of Saneyama Hill, the Jodosawa Gravel includes a few pumices of Tt-E in its uppermost part, showing that the glaciers covered the southern side of Saneyama Hill at the beginning of the pumice fall. The Jodosawa Gravel is covered with the Raichodai Gravel comprising debris flow deposits, indicating that the snouts of glaciers retreated from Saneyama Hill to the upstream during the fall of pumices (Figure 3). Therefore, the glacial retreat seems to have been caused by the pumice fall, not by longterm climate change.

\section{Glacial readvance during deposition of the Murodo Gravel}

Because the Murodo Gravel conformably overlies the Raichodai Gravel without buried soil or weathered layer at Raichodai Hill, the Murodo Gravel seems to have accumulated soon after the deposition of the Raichodai Gravel. The subglacial Murodo Gravel is distributed in the base of Moraine I below the Yamasaki Cirque and in Saneyama Hill. The proglacial Murodo Gravel is distributed in Raichodai Hill, which is situated at the right downstream side of Saneyama Hill. The Murodo Gravel is exposed at the same altitude of around 2,350 $\mathrm{m}$ asl on the northern side of Saneyama Hill and on Raichodai Hill. These facts demonstrate that the glaciers readvanced at around 2,350 $\mathrm{m}$ asl between Saneyama Hill and Raichodai Hill soon after the fall of pumices had finished (Figure 3).

Although the superglacial materials are transported to glacier bed through the crevasses and ice holes (Benn and Evans 1998: 216-221), no pumice is found in the subglacial Murodo Gravel. The pumices are not found in the proglacial Murodo Gravel either. These facts suggest that no pumice cover existed on the readvancing glacier surfaces. Just before this glacial readvance, the glaciers were forcefully melted by the pumice fall, and temporarily retreated upstream. Therefore, the glacial readvance is considered as restoration in size after the end of the pumice fall.

\section{Timing of the larger glacial expansion}

The glacial chronology described above is summarized in Figure 12. The earlier substade represented by the Jodosawa Gravel, Murodo Stade I, is estimated to be 95 to $70 \mathrm{ka}$ (MIS $5 \mathrm{~b}$ to 4) on the basis of its stratigraphic relationships with $\mathrm{K}-\mathrm{Tz}$ (95 to $90 \mathrm{ka}$ ) and the Raichodai Gravel (ca. $70 \mathrm{ka}$ ). Because the glaciers existed continuously on the western slopes of the Tateyama Main Ridge during the deposition of the Jodosawa Gravel and the Raichodai Gravel, Murodo Stade I extended at least until MIS 4. During Murodo Stade I, the glaciers overflowed from the basin, and extended to at least 2,300 m asl within the basin.

The age of the second substade, Murodo Stade II, is defined as 70 to $50 \mathrm{ka}$ (MIS 4 to early MIS 3) based on its stratigraphic relationships with the Raichodai Gravel (ca. $70 \mathrm{ka}$ ) and DKP (52 to $50 \mathrm{ka}$ ). In Murodo Stade II, the glaciers readvanced to around $2,350 \mathrm{~m}$ asl in the study area.

Three terminal moraines (I, II, and III in ascending order) of the Yamasaki Cirque were thought to have been formed between 52 and $8.8 \mathrm{ka}$ (early MIS 3 to early MIS 1, Tateyama Stade) on the basis of their stratigraphic relationships with DKP (52 to $50 \mathrm{ka}$ ) and the peat layer including wood chips (8.8 ka) (Fukai 1975; Machida and Arai 1979; Kobayashi 1990). Each moraine, however, has not been dated in detail because of lack of numerical data. On the high 


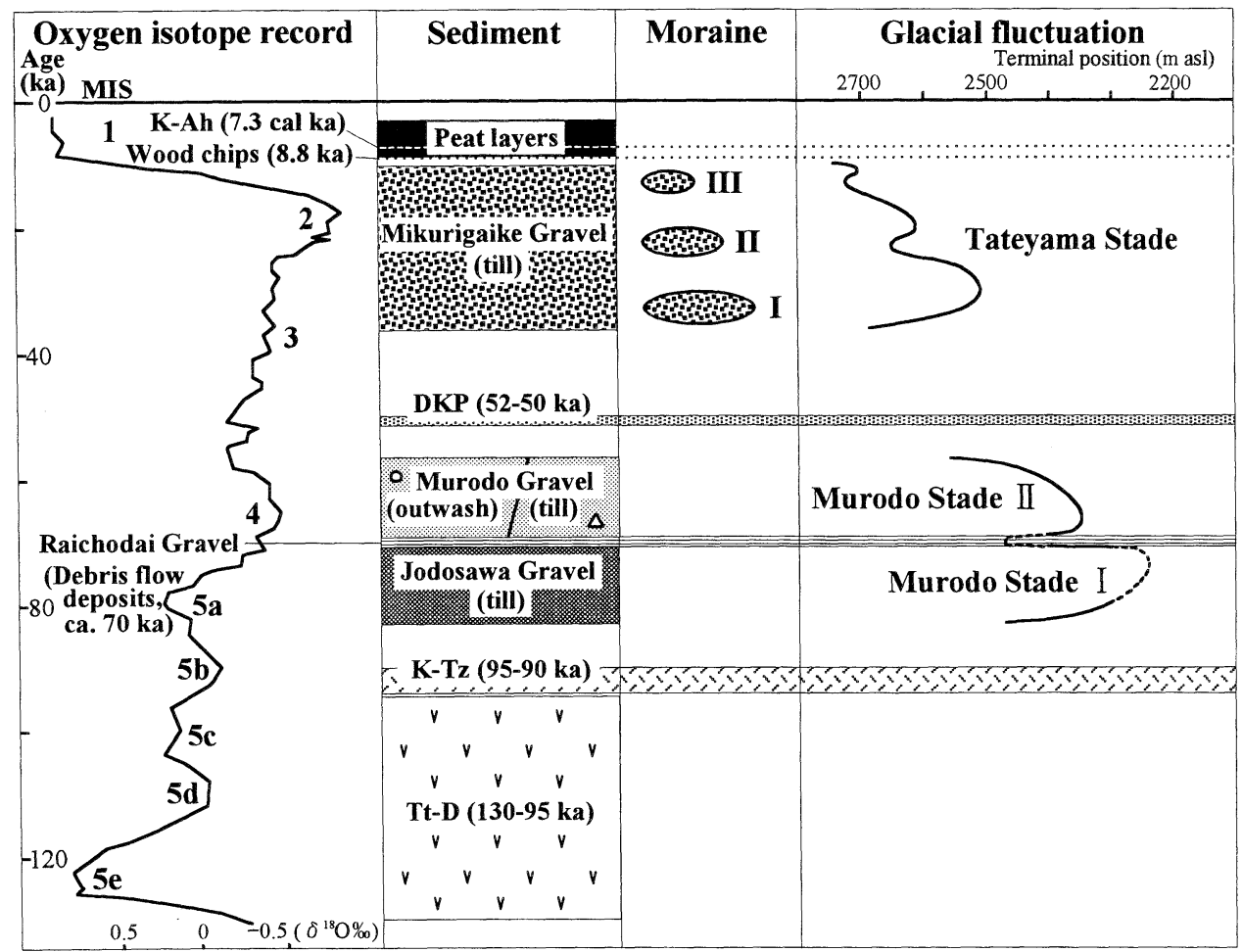

Figure 12. Diagram showing the glacial fluctuations during the Last Glacial period on the western slopes of the Tateyama Main Ridge.

Oxygen isotope record is from Martinson et al. (1987). Ages of tephras and wood chips are from Yoshii and Oritani (1987), Nakamura et al. (1992), Machida and Arai (1992), Kimura (1996), Machida (1999), and Okuno (2002).

mountains of central Japan, the glaciers generally advanced in three substages; just before the fall of Aira-Tanzawa tephra (29 cal ka), in the Last Glacial Maximum (LGM, 20 to $18 \mathrm{ka}$ ), and in the Late Glacial ( 11 to $10 \mathrm{ka}$ ) during the late stade of the Last Glacial period (Hasegawa 1992; Aoki 2002; Okuno 2002). Thus, the glacial advances represented by three moraines of the Yamasaki Cirque are tentatively assigned to these substages in Figure 12. Top surfaces of the terminal moraines I, II, and III lie at 2,520, 2,600 , and $2,705 \mathrm{~m}$ asl respectively (Fukai 1975). On the basis of the terminal moraines and their altitudes, the glaciers of the Yamasaki Cirque appear to have advanced at least three times during Tateyama Stade and reached to $2,520,2,600$, and $2,705 \mathrm{~m}$ asl within the basin. Consequently, the larger glacial expansion of the Last Glacial period occurred during MIS $5 b$ to 4 rather than during MIS 3 on the west side of Mt. Tateyama.

\section{Conclusions}

On the west side of Mt. Tateyama, the Hida Range, central Japan, the larger glacial expansion of the Last Glacial period occurred during MIS $5 \mathrm{~b}$ to 4 (95 to $70 \mathrm{ka}$, Murodo Stade I) rather than during MIS 3. In Murodo Stade I, the glaciers extended from the non-volcanic Tateyama Main Ridge onto the flat surface of the Shomyodaki Pyroclastic Flow Deposits, and reached the Murodo-nokkoshi Saddle. A part of the glaciers crossed to the north side of the saddle. The saddle was only 10 to $20 \mathrm{~m}$ high above the flat surface of the Shomyodaki Pyroclastic Flow Deposits. The glaciers eroded the Shomyodaki Pyroclastic Flow Deposits during this substade, and extended to at least 2,300 m asl in the vicinity of Raichodai Hill. The Jo- 
dosawa Gravel, glacial till of this substade, is distributed in Saneyama Hill, Raichodai Hill, and below and on the Murodo-nokkoshi Saddle.

Between Murodo Stades I and II, the glaciers were forcefully melted by the pumice fall erupted from the Tateyama Volcano. It caused debris flows and the temporary retreat of the glaciers. The Raichodai Gravel, rich in pumices, consists of debris flow deposits, and lies between the Jodosawa Gravel and the Murodo Gravel.

During Murodo Stade II ( 70 to $50 \mathrm{ka}$, MIS 4 to early MIS 3 ), the glaciers readvanced from the Tateyama Main Ridge to around 2,350 $\mathrm{m}$ asl between Saneyama Hill and Raichodai Hill soon after the pumice fall had finished. The subglacial Murodo Gravel is distributed in Saneyama Hill, and the proglacial Murodo Gravel is exposed on Raichodai Hill at around 2,350 m asl.

\section{Acknowledgments}

The author would like to thank H. Hasegawa, T. Aoki and Y. Ono for discussions in the field, and $\mathrm{K}$. Asahi for help in field survey. I also thank S. Iwata, H. Fukusawa and S. Tsukamoto for valuable comments, and I. Tamura for the guidance in tephra identification.

(Received 12 October 2000) (Accepted 28 June 2003)

\section{References}

Aoki T. 2002. Classification and Characteristics of the Distribution of Glacial Landforms in the Japanese Alps. Journal of Geography 111: 498-508. (JE)

Benn, D., and Evans, D. 1998. Glaciers and glaciation. London: Edward Arnold.

Flint, R. F. 1971. Glacial and Quaternary geology. New York: John Wiley and Sons.

Fukai S. 1975. Glacial landforms and their ages in the northern Japanese Alps. In Nihon no hyoki no shomondai, ed. M. Shiki, 1-14. Tokyo: Kokon Shoin. (J)

Gillespie, A., and Molnar, P. 1995. Asynchronous maximum advances of mountain and continental glaciers. Reviews of Geophysics 33: 311-364.

Giraudi, C., and Frezzotti, M. 1997. Late Pleistocene glacial events in the central Apennines, Italy. Quaternary Research 48: 280-290.

Harayama S., Takahashi Y. Nakano S., Kariya Y., and Komazawa M. 2000. Geology of the Tateyama district, With Geological Sheet Map at 1: 50 000, Tsukuba: Geological Survey of Japan. (JE)

Hasegawa H. 1992. Glacial geomorphology and late
Pleistocene glacial fluctuations in the Uchikomi valley, northern Japanese alps. Geographical Review of Japan 65: 320-338. (JE)

Helmens, K. F., Rutter, N. W., and Kuhry, P. 1997. Glacier fluctuations in the eastern Andes of Colombia (South America) during the last 45,000 radiocarbon years. Quaternary International 38/ 39: 39-48.

Iozawa T. 1979. Bird's-eye views of the Japanese Alps. Tokyo: Kodansha. (J)

Iwasaki S., Hirakawa K., and Sawagaki T. 2000a. Late Quaternary glaciation in the Esaoman-Tottabetsu Valley, Hidaka Range, Hokkaido, Japan. Journal of Geography 109: 37-55. (JE)

Iwasaki S., Hirakawa K., and Sawagaki T. 2000b. Late Quaternary glaciation and its chronology in the Tottabetsu Valley, Hidaka Range. Geographical Review of Japan 73A: 498-522. (JE)

Kawasumi T. 2000. Ages of glaciations in the early stage of the late Pleistocene, based on glacial and volcanic deposits in Tateyama, Hida mountains, central Japan. Geographical Review of Japan 73A: 26-43. (JE)

Kimura J. 1996. Lacustrine Takano Formation in Takano Town, Nagano Prefecture. In Inventory of Quaternary Outcrops-Tephras in Japan-Japan Association for Quaternary Research 40th anniversary special publication, ed. Endo K., Kumai H., Machida H., Okumura M., Shimizu T., Suzuki T., Watanabe M., Uesugi A., Ikeda Y., and Tsuji S., 34-35. Tokyo: Japan Association for Quaternary Research. (J)

Kobayashi T. 1990. Quaternary sequence in and around Tateyama Volcano. In The Excursion guide book: 97th Congress of the Geological Society of Japan, ed. Geological Society of Japan, 113142. Toyama: Geological Society of Japan. (J)

Machida H. 1999. Quaternary widespread tephra catalog in and around Japan: recent progress. Quaternary Research 38: 194-201.

Machida H., and Arai F. 1979. Daisen Kurayoshi pumice: stratigraphy, chronology, distribution and implication to late Pleistocene events in central Japan. Journal of Geography 88: 33-50. (JE)

Machida H., and Arai F., 1992. Atlas of tephra in and around Japan. Tokyo: University of Tokyo Press.

Machida H., and Ito N., 1996. Volcanic tephras and lavas erupted onto the glaciers in Mt. Tateyama of the Japanese Northern Alps. In Inventory of Quaternary Outcrops-Tephras in Japan-Japan Association for Quaternary Research 40th anniversary special publication, ed. Endo K., Kumai H., Machida H., Okumura M., Shimizu T., Suzuki T., Watanabe M., Uesugi A., Ikeda Y., and Tsuji S., 250-251. Tokyo: Japan Association for Quaternary Research. (J)

Martinson, D. G., Pisias, N. G., Hays, J. D., Imbrie, J., Moore, T. C. Jr., and Shackleton, N. J. 1987. Age dating and the orbital theory of the ice ages: 
Development of a high-resolution 0 to 300,000 year chronostratigraphy. Quaternary Research 27: $1-29$.

Nakamura T., Oki S., and Sakamoto T. 1992. Radiocarbon ages of charred wood from the Tokyo pumice flow deposit measured with a Tandetron accelerator mass spectrometer. Journal of the Geological Society of Japan 98: 905-908. (J)

Okuno M. 2002. Chronology of tephra layers in southern Kyushu, SW Japan, for the Last 30,000 Years. The Quaternary Research 41: 223-236.

Owen, L. A., Richard, B. M., and Edward, J. R. 1997. Style and timing of glaciation in the Lahul Himalaya, northern India: a framework for reconstructing late Quaternary palaeoclimatic change in the western Himalayas. Journal of Quaternary Science 12: 83-109.

Richards, B. M., Owen, L. A., and Rhodes, E. J. 2000. Timing of late Quaternary glaciations in the Himalayas of northern Pakistan. Journal of Quaternary Science 15: 283-297.
Sugden, D. E., and John, B. S. 1976. Glaciers and landscape. London: Edward Arnold.

Suwa H. 1992. Debris flows observation. Sin sabo 45: $43-51$.

Thouret, J. C., van der Hammen, T., Salomons, B., and Juvigne, E. 1997. Late Quaternary glacial stades in the Cordillera Central, Colombia, Based on glacial geomorphology, tephra-soil stratigraphy, palynology, and radiocarbon dating. Journal of Quaternary Science 12: 347-369.

Yamasaki M., Nakanishi N., and Miyata K. 1966. History of Tateyama Volcano. Scientific Report of Kanazawa University 11: 73-92.

Yoshii R., and Oritani T. 1987. Palynological study of the bog deposits from the Tengudaira, Mt. Tateyama, central Japan. Journal of Phytogeography and Taxonomy 35: 127-136. (J)

$(\mathrm{J})$ in Japanese

(JE) in Japanese with English abstract 